\title{
Moringa oleifera-Rich Diet and T Cell Calcium Signaling in Spontaneously Hypertensive Rats
}

\author{
E. S. ATTAKPA ${ }^{1,3}$, G. A. BERTIN ${ }^{1}$, N. W. CHABI ${ }^{1}$, J.-M. ATÈGBO ${ }^{1}$, B. SERI $^{2}$, \\ N. A. KHAN ${ }^{3}$
}

${ }^{1}$ Laboratoire de Physiopathologie Moléculaire et Toxicologie, Département de Physiologie Animale, Faculté des Sciences et Techniques, Université d'Abomey Calavi, Cotonou, Republic of Benin, ${ }^{2}$ Laboratoire de Neurosciences, Unité de Formation Biosciences, Université de CocodyAbidjan, Abidjan, Republic of Côte d'Ivoire, ${ }^{3}$ INSERM U866, Physiologie de la Nutrition \& Toxicologie, Université de Bourgogne, U.F.R. Sciences de la Vie, Dijon, France

Received June 7, 2016

Accepted February 16, 2017

On-line April 12, 2017

\begin{abstract}
Summary
Moringa oleifera is a plant whose fruits, roots and leaves have been advocated for traditional medicinal uses. The physicochemical analysis shows that Moringa oleifera contains more dietary polyunsaturated fatty acids (PUFA) than saturated fatty acids (SFA). The consumption of an experimental diet enriched with Moringa oleifera extracts lowered blood pressure in spontaneously hypertensive rats (SHR), but not in normotensive Wistar-Kyoto (WKY) rats as compared to rats fed an unsupplemented control diet. Anti-CD3-stimulated $\mathrm{T}$ cell proliferation was diminished in both strains of rats fed the Moringa oleifera. The experimental diet lowered secretion of interleukin-2 in SHR, but not in WKY rats compared with rats fed the control diet. Studies of platelets from patients with primary hypertension and from SHR support the notion that the concentration of intracellular free calcium $\left[\mathrm{Ca}^{2+}\right]_{i}$ is modified in both clinical and experimental hypertension. We observed that the basal, $\left[\mathrm{Ca}^{2+}\right]_{\mathrm{i}}$ was lower in T cells of SHR than in those of WKY rats fed the control diet. Feeding the diet with Moringa oleifera extracts to WKY rats did not alter basal $\left[\mathrm{Ca}^{2+}\right]_{\mathrm{i}}$ in $\mathrm{T}$ cells but increased basal $\left[\mathrm{Ca}^{2+}\right]_{i}$ in SHR. Our study clearly demonstrated that Moringa oleifera exerts antihypertensive effects by inhibiting the secretion of IL- 2 and modulates T cell calcium signaling in hypertensive rats.
\end{abstract}

\section{Key words}

Moringa oleifera • Genetic hypertension • Intracellular calcium • Immunomodulation $\bullet T$ cells $\bullet$ Rats

\section{Corresponding author}

E. S. Attakpa, Laboratoire de Physiopathologie Moléculaire et Toxicologie, Département de Physiologie Animale, Faculté des Sciences et Techniques, Université d'Abomey Calavi, Cotonou, Republic of Benin. E-mail: eattakpa@yahoo.fr

\section{Introduction}

In Africa and Asia, about $80 \%$ of the populations have been reported to depend on traditional medicine for their primary health care including immunomodulation (Chan 2008). A number of medicinal herbs have long been used and reported to boost the immune system or to modulate it and they are used putatively to treat and prevent various disease worldwide (Gulati et al. 2002).

Moringa oleifera Lam (Moringaceae) is a highly valued plant, grown in many countries of the tropics and subtropics. It has an impressive range of medicinal uses with high nutritional value. The medicinal properties of this plant depend on the part of the plant concerned (root, leaf stalk and pulp or fruit) and the extract used (ethanolic, butanolic, aqueous extract etc.). Different parts of this plant contain important minerals, vitamins, beta-carotene, amino acids and various phenolics (Anwar et al. 2007, Kasolo et al. 2010, Mishra et al. 2011, Aja et al. 2014). The Moringa oleifera plant provides a rare combination of zeatin, quercetin, beta-sitosterol, 
caffeoylquinic acid and kaempferol. Various parts of this plant such as the leaves, roots, seed, bark, fruit, flowers and immature pods act as cardiac and circulatory stimulants, possess antitumor, antipyretic, antiepileptic, antiinflammatory, antiulcer, antispasmodic, diuretic, antihypertensive, cholesterol lowering, antioxidant, antidiabetic, hepatoprotective, antibacterial and antifungal activities (Cáceres et al. 1992, Anwar et al. 2007, Mishra et al. 2011, Cáceres et al. 1992, Mbikay 2012, Fahey 2005).

Disorders in the immune system may be responsible for the onset of different pathological states. The immunodeficient diseases result in recurring and life-threatening infections. On the other hand, an autoimmune disease results from a hyperactive immune system attacking normal tissues as if they were foreign organisms (King et al. 2008). Common autoimmune diseases include Hashimoto's thyroiditis, rheumatoid arthritis, type I diabetes and lupus erythematosus. Further investigation in this field is expected to play a serious role in promotion of health and treatment of diseases. The $\mathrm{T}$ lymphocytes are the principal mediators of immune-mediated diseases. Hence, a modification of $\mathrm{T}$ cell activation will be a valuable tool to disrupt the disease progression.

The important role of $\left[\mathrm{Ca}^{2+}\right]_{\mathrm{i}}$ in vascular smooth muscle contraction suggests that abnormal intracellular $\mathrm{Ca}^{2+}$ homeostasis may be involved in the hypertensive process. There is a correlation of blood pressure and platelet $\left[\mathrm{Ca}^{2+}\right]_{\mathrm{i}}$ in hypertensive humans (Le Quan Sang et al. 1986, Brickman et al. 1990, Pritchard et al. 1989). In addition, platelets, lymphocytes and vascular smooth muscle cells from genetically hypertensive rats have elevated $\left[\mathrm{Ca}^{2+}\right]_{\mathrm{i}}$ levels (Oshima et al. 1991, Batlle et al. 1990).

In spontaneously hypertensive rats (SHR), a diet containing eicosapentaenoic acid (EPA)-rich fish oils can attenuate the development of hypertension in young and old animals (Frenoux et al. 2001, Singer et al. 1990). EPA-rich diet also lowered blood pressure, platelet aggregation and improved plasma lipid concentration in humans (Yosefy et al. 1996). Several studies have shown the protective role of dietary (n-3) polyunsaturated fatty acids [(n-3) PUFA] against cardiovascular diseases (Bonaa et al. 1990, Stampfer et al. 2000).

Manhart et al. (2000) observed that after the feeding of rats with a diet containing (n-3) PUFA for 10 days, the production of immunoglobulin IgA was diminished in the Peyer's patches. DHA inhibited not only the infiltration of CD41 cells but also the expression of mRNA for interferon- $\gamma$, IL- 6 , IL-1b and IL-2 in mice fed a DHA-rich diet (Tomobe et al. 2000). Docosahexaenoic acid (DHA) has also been found to diminish significantly the expression of CD4 and CD8 on circulating T lymphocytes (Sasaki et al. 2000b). However, EPA seems to be a more potent immunosuppressive agent than DHA (Hung et al. 1999). It has been shown that the immunosuppressive effects of (n-3) PUFA in different animal models are mediated through $\mathrm{T}$ cell signaling (McMurray et al. 2000, Jolly et al. 1997). Evidence has been put forth in favor of the hypothesis that hypertension may be associated with malfunctioning of the immune system ( $\mathrm{Fu}$ 1995). Circulating immunoglobulins have been found to be higher in subjects with essential hypertension compared with normal subjects (Kristensen 1978, Gudbrandsson et al. 1981), and the presence of autoantibodies against nuclear structures has been reported in malignant hypertension (Gudbrandsson et al. 1981). The presence of autoantibodies against $\beta$-adrenoceptors has been demonstrated in SHR (Hilme et al 1993). Atherosclerosis may also be an autoimmune disease, caused by the molecular mimicry between microbial and human $60-\mathrm{kDa}$ heat shock proteins (Wick 2000). Abnormal activation of the immune system of SHR, along with the loss of suppressor T cells, has been reported (Ofosu-Appiah and Ruggiero 1992).

Although an early study showed that the administration of exogenous IL-2 prevents the increase in blood pressure (BP) in SHR (Tuttle and Boppana 1990), several later studies reported that exogenous IL-2 not only failed to lower BP increases in both animals (Given et al.1992) and humans (Pockaj and Rosenberg 1991), but IL-2 therapy also favored the development of renal dysfunction in most patients (Kruit et al. 1999). In fact, the idea that high levels of circulating cytokines including IL-2 are associated with the development of hypertension is receiving strong support (Kagawa et al. 1999, Matsumori et al. 1994). Peeters et al. (2001) recently demonstrated that proinflammatory cytokines are significantly higher in patients with essential hypertension. Whether altered immune function is a primary factor in the pathogenesis of hypertension or secondary to tissue damage of vascular beds induced by hypertension is still unknown.

Several plausible mechanisms of action of (n-3) PUFA, implicated in BP decrease, have been proposed, i.e. substitution of (n-6) PUFA in plasma membrane 
phospholipids, reduced production of eicosanoids of (n-6) family and inhibition of cyclooxygenase and lipoxygenase activities (Simopoulos 1991). Some earlier studies have tried to demonstrate that Moringa oleifera can modulate the expression of membrane markers on T lymphocytes (Calder 1999, Sasaki et al. 1999). However, little is known about the modulation of the second-messenger cascade, which is implicated in Moringa oleifera-induced immunosuppression during hypertension. Therefore, the present study was conducted to elucidate the influence of a Moringa oleifera-rich diet on $\mathrm{T}$ cell calcium signaling in hypertensive rats.

\section{Methods}

\section{Chemicals}

The culture medium RPMI 1640 and L-glutamine were obtained from BioWhittaker (Liege, Belgium). The fluorescent probe, Fura-2/AM, was procured from Molecular Probes (Eugene, OR). $\left[{ }^{3} \mathrm{H}\right]$-thymidine was purchased from Amersham Radiochemicals (Saclay, France). All other chemicals including thapsigargin, ionomycin and caffeine were obtained from Sigma Chemical (St. Louis, MO).

Plant material and preparation of the aqueous extracts of Moringa oleifera

Moringa oleifera was collected from the south-eastern part of Benin (Abomey-Calavi, in Department of Atlantic) between half July to half August 2015 during the short dry season when the mean temperature equals to $28 \pm 2{ }^{\circ} \mathrm{C}$. This period is preceded by the great rain season (half March to half July). The plant was recognized by the Principal Botanist of National Herbarium of Benin of University of Abomey-Calavi, which contained the voucher specimen (AP-2078-HNB).

A $100 \mathrm{~g}$ of leaves were suspended in $500 \mathrm{ml}$ distilled water and boiled for $30 \mathrm{~min}$. The decoction obtained was filtered, and the filtrate was frozen at $-70{ }^{\circ} \mathrm{C}$ and, later on, lyophilized and stored at ambient temperature until further use. Lyophilized extract was resuspended in physiological saline solution $(\mathrm{NaCl} 0.9 \%$ ) at $1 \mathrm{mg} / \mathrm{ml}$.

\section{Fatty acid composition}

The lipids were extracted as described elsewhere (Hichami et al. 2007) from $1 \mathrm{ml}$ solution of lyophilized extracts $(1 \mathrm{mg} / \mathrm{ml})$ in the presence of internal standard
(C19:0). The lipid extract was dried under nitrogen and saponified and transmethylated at $80{ }^{\circ} \mathrm{C}$ for $20 \mathrm{~min}$ with BF3/methanol (14\%) according to Hichami et al. (2007). Fatty acid methyl esters were then extracted in the presence of $2 \mathrm{ml}$ of hexane and separated by gas-liquid chromatography (Packard model 417 gas-liquid chromatograph (Packard, Downers Grove, IL, USA) equipped with flame ionization detector set at $240{ }^{\circ} \mathrm{C}$ and a 30-m capillary glass column coated with Carbowax 20 M (Applied Science Labs, State College, PA, USA). Helium was used as carrier gas, with a flow rate of $0.4 \mathrm{ml} / \mathrm{min}$. The analysis of fatty acid peaks was achieved with reference to retention time of authentic standards (68b; Nu-Chek-Prep, Elysian, MN, USA) by using DELSI ENICA 31 (Delsi Nermag, Rungis, France). The fatty acid levels were expressed as $\mathrm{g}$ per $100 \mathrm{~g}$ of lyophilized extract of the plant.

\section{Animals and diets}

Male normotensive 3-month-old Wistar-Kyoto (WKY) rats $(\mathrm{n}=20)$ and spontaneously hypertensive rats (SHR) $(n=20)$, weighing from 250 to $430 \mathrm{~g}$, were obtained from IFA-CREDO (L'Arbresle, France). Rats were housed individually in stainless steel cages in a room maintained at $22{ }^{\circ} \mathrm{C}$ with a 12-h light:dark cycle. They were fed with a commercial chow diet for 2 days to stabilize their metabolic condition and allow them to adjust to the new environment. Then, the rats were randomly divided into two groups; one group received control diet (Charles River) throughout the 16-week study (control group). The chemical composition of the control diet was as follows ( $\mathrm{g} / \mathrm{kg}$ dry diet): starch, 587; casein, 200; cellulose, 50; sucrose, 50; mineral mix, 40; vitamin mix, 20; DL-methionine, 3. The treatment protocol was then initiated by adding the Moringa oleifera extract into the diet at three different doses $(200,400,600 \mathrm{mg} / \mathrm{kg})$ for another 8 weeks. Diets were prepared freshly every week and stored at $4{ }^{\circ} \mathrm{C}$. Rats were weighed each week and systolic BP was determined four times by the tail-cuff method. All experiments complied with the local institutional ethical guidelines.

\section{Collection of blood and serum samples}

The rats were fasted overnight, blood samples were collected in a sterile tube by cardiac puncture under ether anesthesia and left to stand at room temperature for $2 \mathrm{~h}$, then centrifuged at $1,500 \mathrm{x}$ g for $15 \mathrm{~min}$ at $4{ }^{\circ} \mathrm{C}$. The supernatant was immediately separated from the pellet to prepare serum samples in order to determine the level of 
triglycerides, LDL, HDL and total cholesterol which were assessed by standard Clinical Biochemistry protocols.

\section{Isolation and preparation of splenic T cells}

The removed spleens were immediately transferred to the Petri dishes, containing RPMI 1640 complete medium, supplemented with the following: $25 \mathrm{mmol} / \mathrm{l}$ HEPES; $2 \mathrm{mmol} / 1$ L-glutamine; $1 \times 10^{5} \mathrm{U} / 1$ penicillin; $100 \mathrm{ml} / 1$ streptomycin; and $100 \mathrm{ml} / 1$ fetal calf serum (FCS). The spleens were teased apart using a wire gauge. The number of viable cells was determined using the Trypan blue exclusion test. After centrifugation ( $200 \mathrm{xg}, 5 \mathrm{~min})$, the cells were resuspended in PBS, $\mathrm{pH}$ 7.4, and placed in a sterile Petri dish for $1 \mathrm{~h}$ at $37^{\circ} \mathrm{C}$ to remove the macrophages by adherence. T lymphocytes were isolated by panning. In brief, the unadhered cells were decanted and centrifuged $(200 \mathrm{xg}, 5 \mathrm{~min})$ once with PBS-containing bovine serum albumin ( $2 \mathrm{~g} / \mathrm{l}$ BSA), and were transferred to the Petri dishes that were previously coated with anti-rat $\operatorname{IgG}(37.5 \mathrm{mg} / 15 \mathrm{ml})$ overnight at $4{ }^{\circ} \mathrm{C}$.

Hence, selective depletion of B lymphocytes was accomplished because they adhered to the substratum of the Petri dishes. After the incubation for $1 \mathrm{~h}$ at $4{ }^{\circ} \mathrm{C}$, the $T$ lymphocyte-rich supernatant was decanted and centrifuged $(200 \mathrm{xg}, 5 \mathrm{~min})$ twice with PBS-BSA and resuspended in the same buffer. This technique provided us with an enriched (99\%) T cell population as verified by flow cytofluorometry (not shown). The cell viability was again checked by employing the Trypan blue test.

\section{Measurement of $\mathrm{Ca}^{2+}$ signaling}

The $\mathrm{T}$ cells $\left(2 \times 10^{9} / 1\right)$, isolated by the panning technique, were washed with $\mathrm{PBS}, \mathrm{pH} 7.4$, and then loaded with Fura-2/AM ( $1 \mathrm{mmol} / \mathrm{l})$ for $60 \mathrm{~min}$ at $37^{\circ} \mathrm{C}$ in loading buffer which contained (in $\mathrm{mmol} / \mathrm{l}$ ): $\mathrm{NaCl}, 110$; $\mathrm{KCl}, 5.4 ; \mathrm{NaHCO}_{3}, 25 ; \mathrm{MgCl}_{2}, 0.8 ; \mathrm{KH}_{2} \mathrm{PO}_{4}, 0.4$; HEPES-Na, 20; $\mathrm{NaHPO}_{4}, 0.33$; and $\mathrm{CaCl}_{2}, 1.2$; the $\mathrm{pH}$ was adjusted to 7.4. After loading, the cells were washed three times $(2,000 \mathrm{xg}, 10 \mathrm{~min})$ and remained suspended in the identical buffer. Intracellular free calcium $\left(\left[\mathrm{Ca}^{2+}\right]_{\mathrm{i}}\right)$ was measured according to Grynkiewicz et al. (1985). The fluorescence intensities were measured in the ratio mode in a PTI spectrofluorometer at $340 \mathrm{~nm}$ and $380 \mathrm{~nm}$ (excitation filters) and $510 \mathrm{~nm}$ (emission filters). The cells were stirred continuously throughout the experiment. The test molecules were added into the cuvettes in small volumes with no interruptions in recordings. The $\left[\mathrm{Ca}^{2+}\right]_{\mathrm{i}}$ were calculated using the following equation:

$$
\left[\mathrm{Ca}^{2+}\right]_{\mathrm{i}}=K_{d} \mathrm{x}\left(R-R_{\min }\right) /\left(F_{\max }-F\right)\left(S_{\mathrm{f} 2} / S_{\mathrm{b} 2}\right)
$$

A value of 224 for $K_{\mathrm{d}}$ was added into the calculations. $R_{\max }$ and $R_{\min }$ values were obtained by addition of ionomycin $(5 \mathrm{mmol} / \mathrm{l})$ and $\mathrm{MnCl}_{2}(2 \mathrm{mmol} / \mathrm{l})$, respectively. The experiments were performed at $35^{\circ} \mathrm{C}$ instead of $37^{\circ} \mathrm{C}$ to minimize the leakage of Fura-2. For each rat, $\left[\mathrm{Ca}^{2+}\right]_{i}$ measurements were done at least in quadruplicate.

\section{T cell blastogenesis}

For $\mathrm{T}$ cell blastogenesis, all splenocytes, without eliminating accessory and B cells, were used. The cells $\left(2 \times 10^{5}\right.$ cells/well) were cultured in 96-well flat-bottomed tissue culture plates (Nunc, Paris, France) in the presence or absence of anti-CD3 antibodies $(30 \mu \mathrm{g} / \mathrm{ml})$. Cells were distributed in six replicates as follows: $160 \mu \mathrm{l}$ of cell suspension and $20 \mu \mathrm{l}$ of anti-CD3 antibodies as described elsewhere (Aires 2004). After $36 \mathrm{~h}, 20 \mu \mathrm{l}$ of $\left[{ }^{3} \mathrm{H}\right]$ thymidine $(20 \mathrm{Ci} / \mathrm{mmol}, 0.5 \mu \mathrm{Ci} /$ well $)$ were added and, $12 \mathrm{~h}$ later, the cells were harvested with a cell harvester (Dynatech, Burlington, MA, USA), trapping their DNA onto glass filtermats. Dried filter circles were placed in plastic minivials (Packard, Downers Grove, IL, USA), $2 \mathrm{ml}$ of Optifluor-O (Packard) was added, and the radioactivity was recorded in a scintillation counter (Beckman, Fullerton, CA, USA).

\section{ELISA for IL-2 determination}

Splenic T lymphocytes $\left(2 \times 10^{5}\right.$ cells/well $)$ were isolated and then stimulated with anti-CD3 antibodies $(30 \mu \mathrm{g} / \mathrm{ml})$. After $72 \mathrm{~h}$, the supernatants were removed by centrifugation $(200 \mathrm{xg}, 5 \mathrm{~min})$ and stored at $-80^{\circ} \mathrm{C}$. Culture supernatants were thawed, gently vortexed and centrifuged $(100 \mathrm{xg}, 1 \mathrm{~min})$ and an aliquot $(50 \mu \mathrm{l})$ was used for IL-2 quantification using a commercially available kit (R \& D System, Oxford, UK).

\section{Analysis of phospholipids}

The lipids from $\mathrm{T}$ lymphocytes were extracted according to the method of Bligh and Dyer (1959). Phospholipids were separated on silica gel by TLC, using the solvent chloroform/methanol/acetic acid at 35:14:2.7 $(\mathrm{v} / \mathrm{v} / \mathrm{v})$. The phospholipids were scraped and extracted from silica by using chloroform/methanol/2 mol/l $\mathrm{NaCl}$ at 5:5:1 (v/v/v). The plasma membrane phospholipids, after methylation at $80^{\circ} \mathrm{C}$ for $20 \mathrm{~min}$ by $\mathrm{BF} 3 /$ methanol, were analyzed on TLC plates. The spots from the TLC plates were scraped off and fatty acids were extracted with $2 \mathrm{ml}$ 
isooctane and separated by gas-liquid chromatography in a Packard Model 417 gas-liquid chromatograph, equipped with a flame ionization detector and a 30-m capillary gas column coated with Carbowax 20M. The analysis conditions were as follows: oven, $194{ }^{\circ} \mathrm{C}$ and injector and ionizing detector, $240{ }^{\circ} \mathrm{C}$. Helium was used as carrier gas, with a flow rate of $0.4 \mathrm{ml} / \mathrm{min}$. Analysis of fatty acid peaks was achieved with reference to the internal standards (Nu-Chek-Prep, Elysian, MN) by using DELSI ENICA 31 (Delsi Nermag, Rungis, France). The fatty acid levels were expressed as percentage of total fatty acids.
Statistics

Data were expressed as means \pm SEM. The significance of the differences between experimental groups was evaluated using two-way ANOVA followed by the Least Significant Difference test.

\section{Results}

Fatty acid compositions

As observed in this study, Moringa oleifera leaves contain more dietary polyunsaturated fatty acids than the saturated fatty acids (Table 1).

Table 1. Fatty acid composition of Moringa oleifera leaves.

\begin{tabular}{lc}
\hline Parameters & Quantity (\%) \\
\hline Total saturated fatty acids (SFA) & $49.21 \pm 0.70$ \\
Total monounsaturated fatty acids (MUFA) & $3.55 \pm 0.90$ \\
Total polyunsaturated fatty acids (PUFA) & $60.30 \pm 1.96$ \\
Total omega-6 fatty acids (n-6) & $9.70 \pm 0.05$ \\
Total omega-3 fatty acids (n-3) & $48.57 \pm 1.92$ \\
PUFA : SFA & $1.22 \pm 0.07$ \\
$n-6 / n-3$ & $0.19 \pm 0.01$ \\
PUFA : MUFA & $16.98 \pm 6.21$ \\
Trans fatty acids & $0.00 \pm 0.01$ \\
\hline
\end{tabular}

Values are mean \pm SEM. Each value represents the mean of three determinations.

Effects of Moringa oleifera on the body and organ weights during the experiment

The body weight of normotensive WKY rats and spontaneously hypertensive rats (SHR), which were fed either control or Moringa oleifera-supplemented diet, was measured in the same rats in which organ weight was determined (Table 2). There were no significant differences in the initial body weights among the groups. The present study showed that Moringa oleifera did not affect the body weight in either rat strain during the experiment (Figs 1 and 2). Moreover, Moringa oleifera did not change organ weights in normotensive WKY rats. SHR fed a control diet had significantly higher weight of retroperitoneal, epididymal and brown fat pads as compared to WKY rats (Table 2). When the rats were treated with Moringa oleifera, SHR had significantly smaller livers as well as epididymal and brown fat than normotensive WKY rats (Table 2).

Table 2. Organ weights at the end of the experiment.

\begin{tabular}{lcccc}
\hline \multirow{2}{*}{ Organ weights } & \multicolumn{2}{c}{ WKY } & \multicolumn{2}{c}{ SHR } \\
& Control & Moringa oleifera & Control & Moringa oleifera \\
\hline Liver (g) & $4.50 \pm 0.60$ & $4.40 \pm 0.30$ & $5.50 \pm 0.10$ & $2.30 \pm 0.10^{\#}$ \\
Retroperitoneal fat $(g)$ & $0.87 \pm 0.03$ & $0.80 \pm 0.10$ & $1.66 \pm 0.08^{\#}$ & $0.77 \pm 0.01^{*}$ \\
Epididymal fat $(g)$ & $1.50 \pm 0.05$ & $1.48 \pm 0.02$ & $1.90 \pm 0.12^{\#}$ & $0.53 \pm 0.13^{* \#}$ \\
Brown fat $(g)$ & $0.30 \pm 0.01$ & $0.35 \pm 0.02$ & $0.42 \pm 0.03^{\#}$ & $0.89 \pm 0.02^{* \#}$ \\
\hline
\end{tabular}

Values are mean $\pm S E M, n=5$; significantly different $(p<0.05)$ from: * corresponding group of WKY rats, $*$ SHR fed a control diet. 

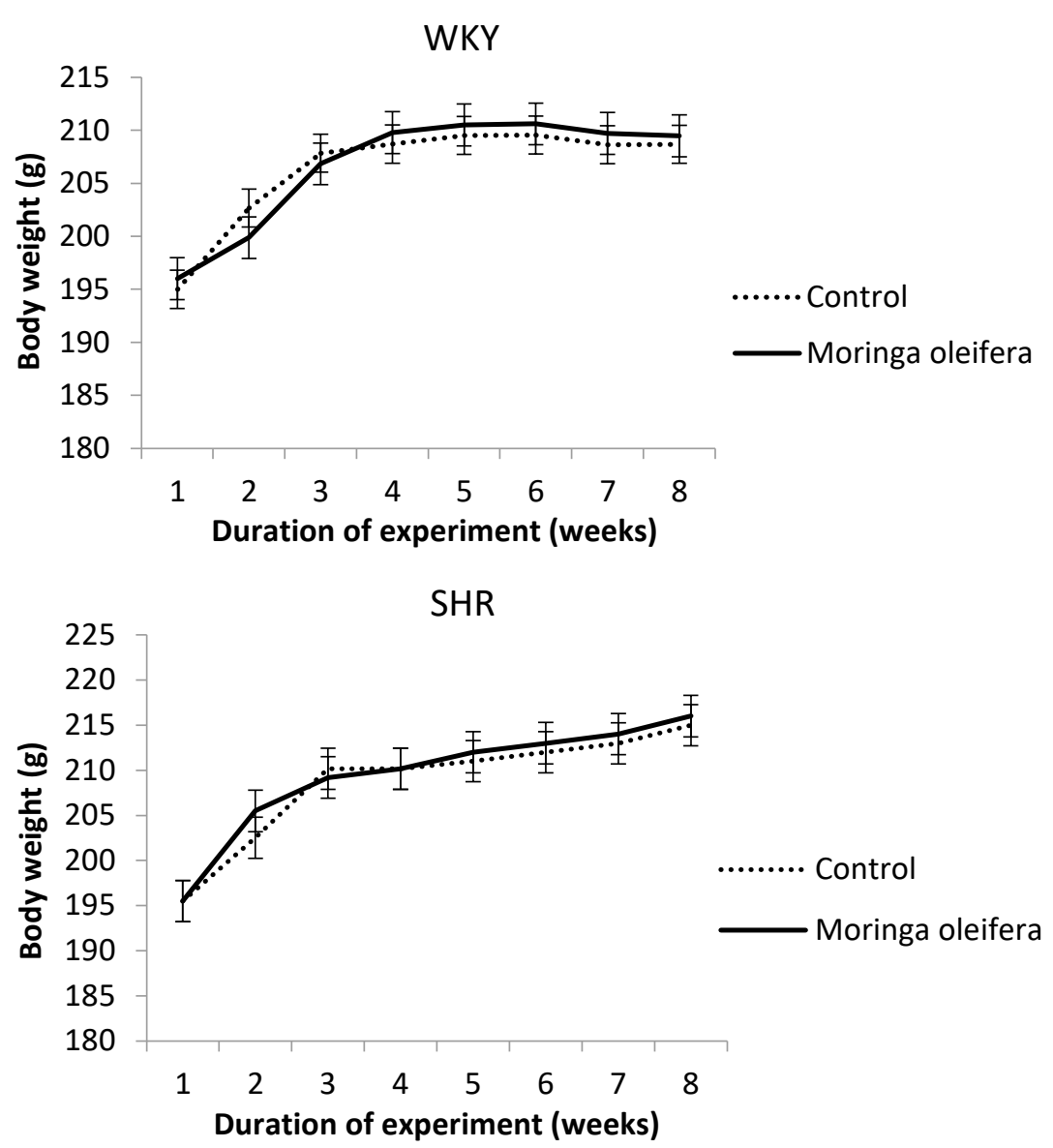

Fig. 1. The feeding of a diet with Moringa oleifera extract did not affect body weight of normotensive WistarKyoto rats (WKY). Values are means $\pm S E M, n=5$ rats. Each value is the mean of six replicates.

Fig. 2. The feeding of a diet with Moringa oleifera extract did not affect body weight of spontaneously hypertensive rats (SHR). Values are means $\pm S E M, n=5$ rats. Each value is the mean of six replicates.
Effects of Moringa oleifera on blood glucose and serum lipid levels

Dietary Moringa oleifera decreased significantly blood glucose as well as serum triglycerides, LDL and total cholesterol levels in SHR, whereas this diet increased LDL level in WKY rats (Table 3).

Effects of Moringa oleifera extract on blood pressure

Our study demonstrated the antihypertensive effects of Moringa oleifera extract in hypertensive rats. Moringa oleifera extract dose-dependently decreased blood pressure of spontaneously hypertensive rats (SHR)
(Fig. 3). The Moringa oleifera effects were statistically different between $200 \mathrm{mg} / \mathrm{kg}$ and $400 \mathrm{mg} / \mathrm{kg}$ but they were not statistically different between $400 \mathrm{mg} / \mathrm{kg}$ and $600 \mathrm{mg} / \mathrm{kg}$. Therefore we employed Moringa oleifera extract at $400 \mathrm{mg} / \mathrm{kg}$ in the further experiments. Figure 4 shows that Moringa oleifera $(400 \mathrm{mg} / \mathrm{kg})$ treatment did not completely normalize blood pressure (BP) of SHR, but it decreased BP significantly in these animals compared with SHR fed the control diet. The Moringa oleifera diet did not affect BP in normotensive WKY rats (duration of experiment: weeks) (Fig. 5).

Table 3. Effects of Moringa oleifera on blood glucose and serum lipids.

\begin{tabular}{|c|c|c|c|c|}
\hline & \multicolumn{2}{|c|}{$\begin{array}{c}\text { WKY } \\
\text { (week } 1 \text { and week 8) }\end{array}$} & \multicolumn{2}{|c|}{$\begin{array}{c}\text { SHR } \\
\text { (week } 1 \text { and week 8) }\end{array}$} \\
\hline & Control & Moringa oleifera & Control & Moringa oleifera \\
\hline Glucose (mmol/l) & $7.45 \pm 0.16$ & $7.43 \pm 0.15$ & $11.20 \pm 0.67^{\#}$ & $6.80 \pm 0.39 *$ \\
\hline Triglycerides $(\mathrm{mmol} / \mathrm{l})$ & $0.64 \pm 0.09$ & $0.63 \pm 0.08$ & $0.90 \pm 0.04$ & $0.36 \pm 0.05^{* \#}$ \\
\hline$L D L(\mathrm{mmol} / \mathrm{l})$ & $0.76 \pm 0.08$ & $1.75 \pm 0.17 *$ & $1.97 \pm 0.09^{\#}$ & $0.74 \pm 0.11 *^{\#}$ \\
\hline$H D L(\mathrm{mmol} / \mathrm{l})$ & $1.30 \pm 0.05$ & $1.29 \pm 0.04$ & $1.25 \pm 0.04$ & $1.98 \pm 0.03 * \#$ \\
\hline Total cholesterol $(\mathrm{mmol} / \mathrm{l})$ & $1.65 \pm 0.01$ & $1.63 \pm 0.01$ & $3.35 \pm 0.12^{\#}$ & $1.96 \pm 0.10 * *$ \\
\hline
\end{tabular}

Values are mean \pm SEM. $n=5$; significantly different $(p<0.05)$ from: ${ }^{*}$ corresponding group of WKY rats, $*$ SHR fed a control diet. 


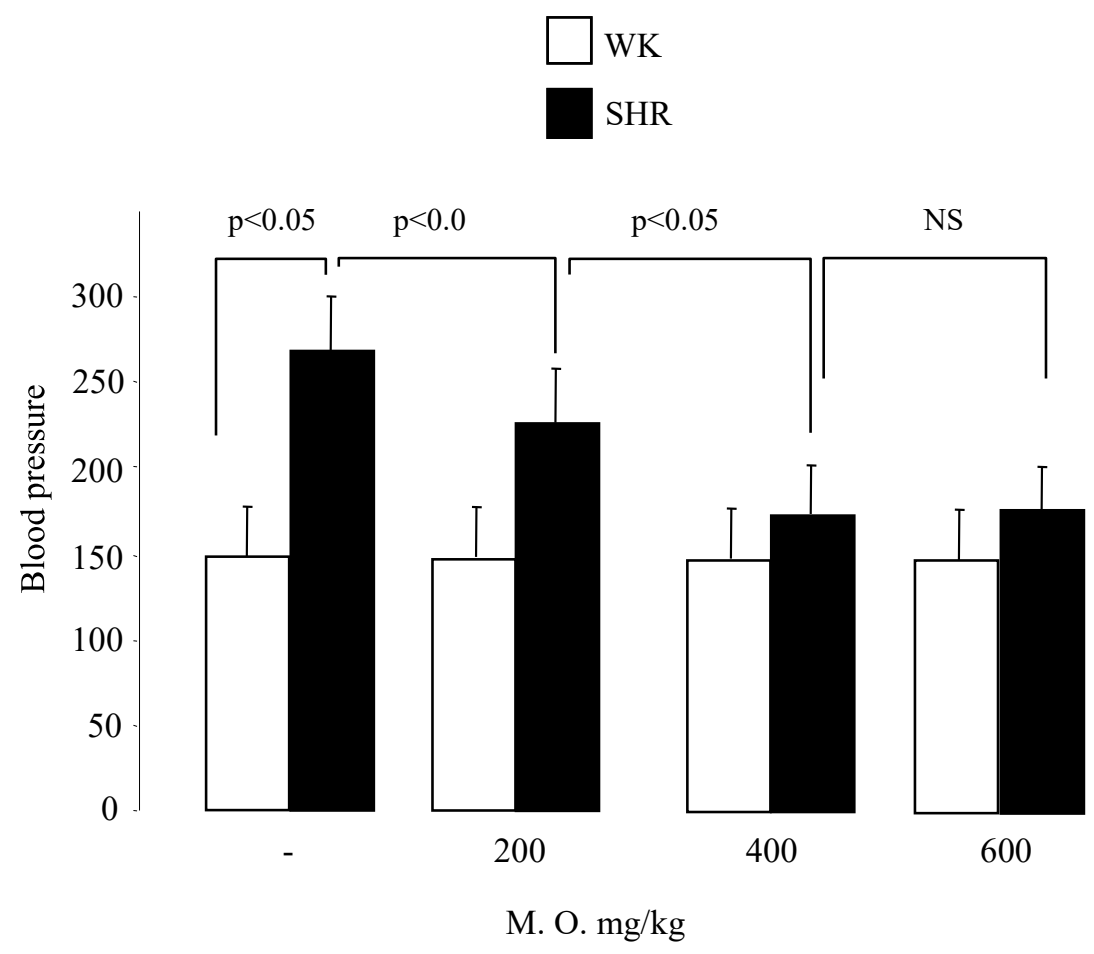

Blood pressure of SHR
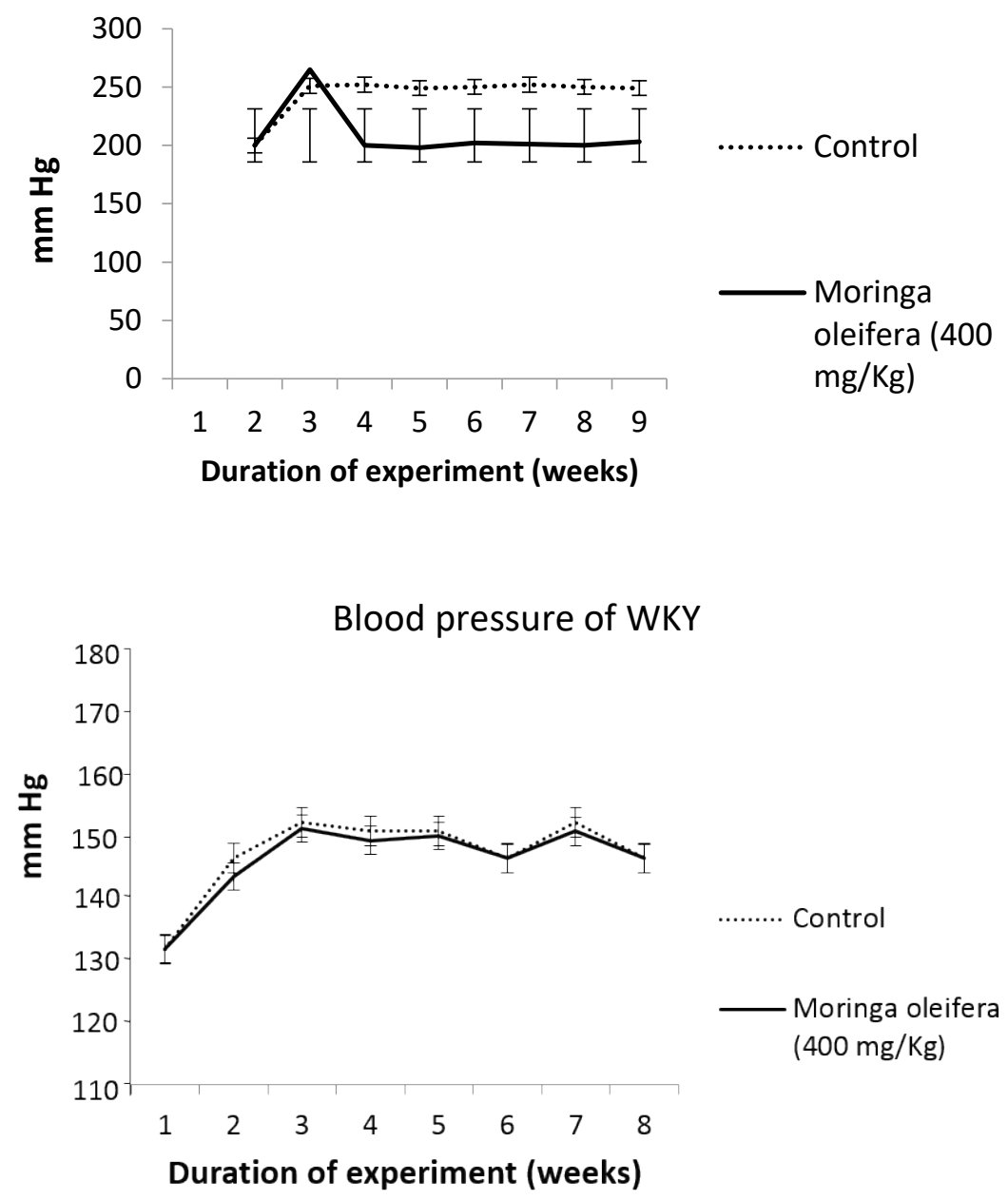

Fig. 3. The feeding of a diet with Moringa oleifera (M. O.) extract dosedependently decreased blood pressure of SHR but not in WKY. Values are means $\pm S E M, n=15$ in each group of animals.
Fig. 4. The Moringa oleifera diet $(400 \mathrm{mg} / \mathrm{kg})$ decreased but did not completely normalize blood pressure of SHR. Values are means $\pm \mathrm{SEM}$, $n=5$ rats. Each value is the mean of six replicates. * Significantly different $(p<0.05)$ between dietary groups within a strain.

Fig. 5. The Moringa oleifera diet did not affect BP in WKY rats. Values are means $\pm S E M, n=5$ rats. Each value is the mean of six replicates. 
Moringa oleifera dietary exerts immunomodulatory effects on T cell activation

Moringa oleifera exerted an inhibitory effect on T cell proliferation (Fig. 6). These inhibitory effects were statistically different between $200 \mathrm{mg} / \mathrm{kg}$ and $400 \mathrm{mg} / \mathrm{kg}$ but they were not statistically different between $400 \mathrm{mg} / \mathrm{kg}$ and $600 \mathrm{mg} / \mathrm{kg}$. The inhibitory effects of Moringa oleifera at $400 \mathrm{mg} / \mathrm{kg}$ were not caused by the

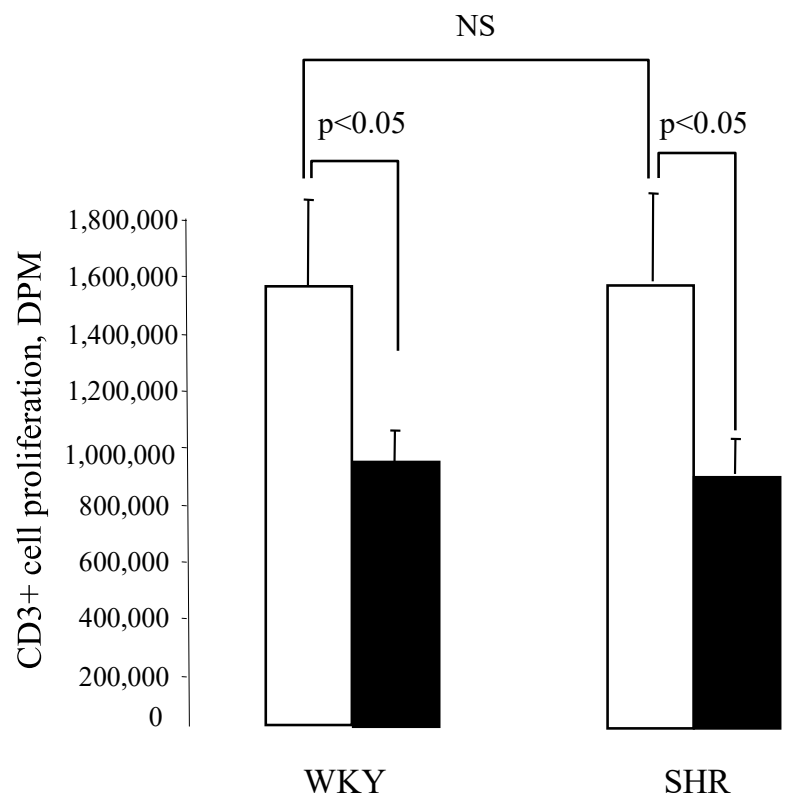

\section{Secretion of IL-2}

Anti-CD3 antibodies-stimulated T cells of SHR fed the control diet secreted more IL-2 than WKY rats fed the control diet. The feeding of Moringa oleifera diet diminished IL-2 secretion in T cells of SHR, but not in those of WKY rats (Fig. 7).

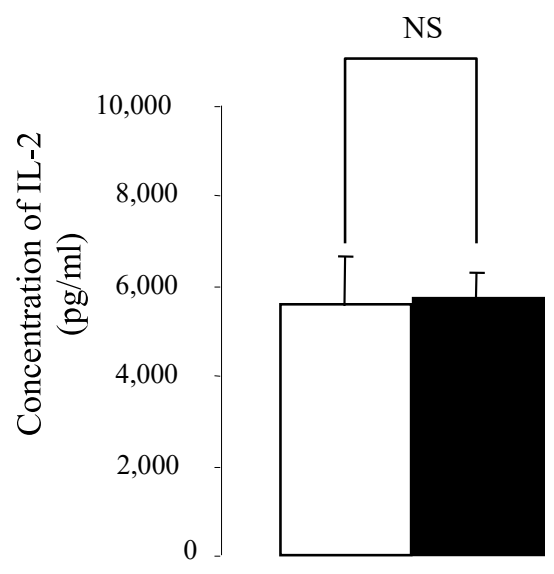

WKY

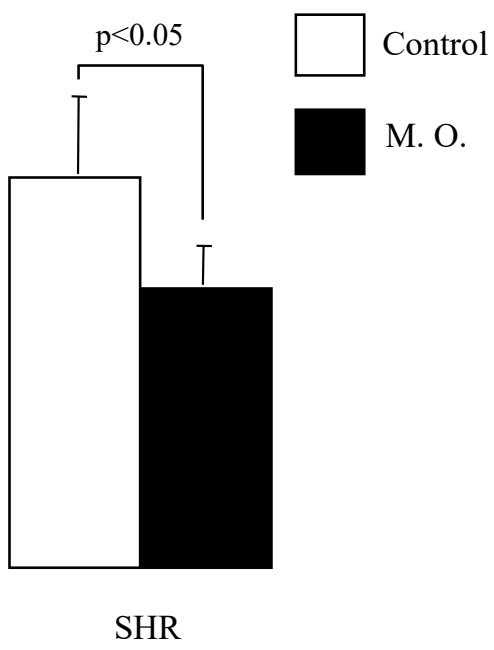

Fig. 6. The Moringa oleifera (M. O.) diet exerted immunomodulatory effects on anti-CD3-stimulated $T$ cell blastogenesis in WKY and SHR. Values are means $\pm S E M, n=5$ rats in each group (each value is the mean of six measurements).
Moringa oleifera dietary treatment modulates intracellular calcium signaling

We observed that the basal intracellular free calcium concentrations $\left[\mathrm{Ca}^{2+}\right]_{\mathrm{i}}$ in $\mathrm{T}$ cells of SHR were lower than in those of WKY rats fed the control diet. Feeding of Moringa oleifera diet did not alter basal $\left[\mathrm{Ca}^{2+}\right]_{\mathrm{i}}$ in $\mathrm{T}$ cells of WKY rats but increased basal $\left[\mathrm{Ca}^{2+}\right]_{\mathrm{i}}$ in those of SHR (Fig. 8).

Fig. 7. The Moringa oleifera (M. O.) diet modulated secretion of IL-2 in WKY and SHR. Values are means \pm SEM, $n=5$ rats in each group (each value is the mean of six measurements). 


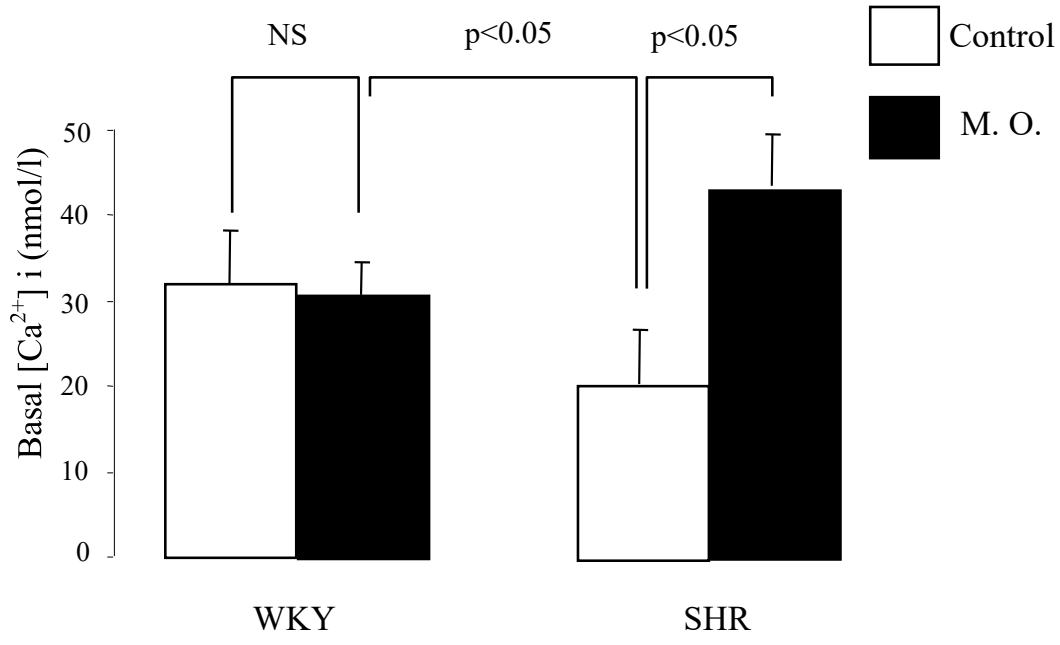

Fig. 8. The Moringa oleifera (M. O.) diet modulated basal concentrations of free intracellular calcium $\left(\left[\mathrm{Ca}^{2+}\right]_{i}\right.$ in purified $T$ cells of WKY and SHR. Values are means \pm SEM, $n=5$ rats in each group (each value is the mean of 15 measurements).

Polyunsaturated fatty acids (n-3) replace fed the Moringa oleifera diet (Table 4). The polyunsaturated fatty acids (n-6) in T cell phospholipids concentrations of arachidonic acid were lower in the Polyunsaturated fatty acids (n-3), which were phospholipids of rats fed the Moringa oleifera diet absent from the phospholipids of $\mathrm{T}$ cells of rats fed the control diet, were present in both strains of rats fed the Moringa oleifera diet. The concentrations of EPA and compared with those fed the control diet. The concentrations of arachidonic acid were higher in $\mathrm{T}$ cells from SHR than in those from WKY rats (Table 4).

Table 4. Fatty acid composition of plasma membrane phospholipids of T lymphocytes from WKY or SHR fed control or Moringa oleifera diet.

\begin{tabular}{|c|c|c|}
\hline Fatty acid (g/100 g fatty acids) & Control diet & Moringa oleifera diet \\
\hline \multicolumn{3}{|c|}{ WKY } \\
\hline 14:0 & $2.95 \pm 0.03$ & $3.81 \pm 0.30$ \\
\hline 16:0 & $26.14 \pm 0.88$ & $31.15 \pm 0.99 *$ \\
\hline $18: 0$ & $31.55 \pm 0.78$ & $27.31 \pm 0.79^{*}$ \\
\hline $18: 1(n-7+n-9)$ & $17.05 \pm 0.65$ & $15.98 \pm 0.62$ \\
\hline $18: 2(n-6)$ & $15.48 \pm 1.30$ & $13.81 \pm 1.55$ \\
\hline $20: 4(n-6)(A A)$ & $12.84 \pm 0.20$ & $6.02 \pm 0.25 *$ \\
\hline $20: 5(n-3)(E P A)$ & ND & $4.35 \pm 0.21$ \\
\hline $22: 5(n-3)(D P A)$ & ND & $4.59 \pm 0.23$ \\
\hline $22: 6(n-3)(D H A)$ & ND & $2.00 \pm 0.20$ \\
\hline \multicolumn{3}{|c|}{ SHR } \\
\hline $14: 0$ & $2.29 \pm 0.10^{\$}$ & $2.29 \pm 0.12^{\$}$ \\
\hline 16:0 & $28.11 \pm 0.58$ & $25.66 \pm 0.33^{* \$}$ \\
\hline $18: 0$ & $21.26 \pm 1.74^{\$}$ & $17.56 \pm 0.45^{* \$}$ \\
\hline $18: 1(n-7+n-9)$ & $17.60 \pm 1.62$ & $19.52 \pm 0.90^{\$}$ \\
\hline $18: 2(n-6)$ & $9.39 \pm 0.50^{\$}$ & $11.18 \pm 0.35$ \\
\hline $20: 4(n-6)(A A)$ & $27.36 \pm 0.90^{\$}$ & $12.37 \pm 0.54^{* \$}$ \\
\hline $20: 5(n-3)(E P A)$ & ND & $9.59 \pm 0.37^{\$}$ \\
\hline $22: 5(n-3)(D P A)$ & ND & $9.53 \pm 0.34^{\$}$ \\
\hline $22: 6(n-3)(D H A)$ & ND & $4.31 \pm 0.18^{\$}$ \\
\hline
\end{tabular}

Values are means \pm SEM, $n=5 ; N D$, not determined. AA - arachidonic acid, DPA - docosapentaenoic acid. * significantly different $(p<0.05)$ between diet groups within a strain; ${ }^{\$}$ significantly different $(p<0.05)$ between strains fed the same diet. 


\section{Discussion}

Polyunsaturated fatty acids are important for human and animal health. They are precursors of long chain n-3 PUFA in the biosynthesis of eicosanoids, which are important bioregulators of many cellular processes (Khotimchenko 2005). They are linked to the development and function of the immune system. Consumers should prefer food low in saturated fatty acids (SFA) which are associated with an increased risk of cardiovascular diseases and some cancers (Griffin 2008, Alfaia et al. 2009) and they should increase the intake of polyunsaturated fatty acids (PUFA), particularly n-3 PUFA at the expense of n-6 PUFA (Hoffman and Wiklund 2006, Alfaia et al. 2009). The quantity and composition of fatty acids in the body are related to the presence of their precursors in the diet, since some of the fatty acids are absorbed in the body unchanged (Wood et al. 2004).

Our findings corroborate several studies in which a diet enriched with (n-3) PUFA exerted antihypertensive effects in humans and experimental animals (Frenoux et al. 2001, Yosefy et al. 1996). Anti-CD3-stimulated $T$ cell proliferation was not significantly different in the studied strains of rats and the Moringa oleifera diet significantly curtailed T cell blastogenesis (Fig. 6). Nonetheless, the secretion of IL-2 by mitogen-stimulated $\mathrm{T}$ cells was higher in SHR than that in WKY rats (Fig. 7). These observations suggest that T cells from SHR secrete more IL-2 than those from WKY rats. It is possible that in vivo activation of the immune system during hypertension may be responsible for this difference in ex vivo secretion.

Our findings corroborate several studies that have demonstrated the abnormal activation of the immune system during hypertension (Kristensen 1978, Gudbrandsson et al. 1981, Ofosu-Appiah and Ruggiero 1992, Peeters et al. 2001). High secretion of cytokines is correlated with the severity of hypertension in humans (Kagawa et al. 1999, Matsumori et al. 1994). Since the T cells from SHR secrete high concentrations of IL-2, the immunosuppressive action of Moringa oleifera can be more pronounced in these cells. As expected, the Moringa oleifera diet decreased IL-2 secretion only in anti-CD3-stimulated T cells of SHR. Our observations agree well with the findings of several authors who have also observed the decreased production of IL-2 (Endres et al. 1993) and suppressed mitogen-induced T cell proliferation in fish oil-fed rats (Sasaki et al. 2000a) and mice (McMurray et al. 2000, Jolly et al. 1997).

In our study, we have observed that the Moringa oleifera diet reduced the increase in BP in SHR without affecting BP in WKY rats. This treatment did not influence the body weight in either rat strain (Figs 1 and 2). Our findings corroborate several studies in which a diet enriched with (n-3) PUFA exerted antihypertensive effects in humans and experimental animals (Frenoux et al. 2001, Yosefy et al. 1996). The Moringa oleifera did not affect organ weights in normotensive WKY rats. Triglyceride levels decreased significantly under the influence of plant extract in SHR. These results were fully compatible with the changes observed in SHR treated with Moringa oleifera, which had significantly smaller livers than normotensive controls. The Moringa oleifera diet decreased plasma levels of glucose, triglycerides, LDL and total cholesterol in SHR indicating that this diet could prevent atherosclerosis (Table 3). The present study showed antihypertensive effects of Moringa oleifera extract in SHR in which this extract dose-dependently decreased blood pressure (Fig. 3). The Moringa oleifera effects were not significantly different between $400 \mathrm{mg} / \mathrm{kg}$ and $600 \mathrm{mg} / \mathrm{kg}$. We therefore used the diet with $400 \mathrm{mg} / \mathrm{kg}$ of Moringa oleifera extract. Such a treatment did not completely normalize BP of $\mathrm{SH}$, but it decreased BP in these rats as compared with SHR fed the control diet (Fig. 4). The Moringa oleifera diet did not affect BP in normotensive WKY rats (Fig. 5).

The Spearman's correlation coefficient (Rs) between antioxidant activity and vitamins or fatty acids were as follows: vitamin A vs. antioxidant $\mathrm{Rs}=0.95$; vitamin $\mathrm{C}$ vs. antioxidant $\mathrm{Rs}=0.82$; vitamin $\mathrm{E}$ vs. antioxidant $\mathrm{Rs}=0.68$; n-fatty acids vs. antioxidant $\mathrm{Rs}=0.27$. Hence, it is possible that the fatty acids might be responsible for this immunosuppressive effect. The Spearman's correlation coefficient between $T$ cell proliferation (TCP) and vitamins or fatty acids are as follows: vitamin A vs. TCP $\mathrm{Rs}=0.0037$; vitamin $\mathrm{C}$ vs. TCP Rs $=0.19$; vitamin E vs. TCP Rs=0.15; $n-3$ fatty acids vs. TCP Rs=0.70. Indeed, seed fraction was the richest in fatty acids and it contained three immunosuppressive $n-3$ fatty acids (18:3, n-3; 20:3, n-3 and 20:3). In fact, the fatty acid composition depends on culture type (irrigation or not), location, and developmental stage (mature or raisin) which may vary from one country to another. It has been well established that n-3 fatty acids exert immunosuppressive and antiinflammatory activities both in experimental and clinical studies (Calder et al. 2006). 
Indeed, the extracts of Moringa oleifera have been shown to possess antiinflammatory properties (Baytop 1984).

EPA and DHA, which were absent from the phospholipids of $\mathrm{T}$ cells of rats fed the control diet, were present in both strains of rats fed the Moringa oleifera diet. The concentrations of EPA and DHA were significantly $(\mathrm{p}<0.05)$ higher in SHR than in WKY rats fed Moringa oleifera diet (Tables 1 and 2). The concentrations of arachidonic acid were lower $(\mathrm{p}<0.05)$ in the phospholipids of rats fed the Moringa oleifera diet compared with those fed the control diet. The concentrations of arachidonic acid were higher in $\mathrm{T}$ cells from SHR than in those from WKY rats (Tables 1 and 2) $(\mathrm{p}<0.05)$.

Substantial evidence has been obtained in studies of platelets from patients with primary hypertension (Cooper et al. 1987) and from SHR (Bruschi et al. 1985) that the concentration of $\left[\mathrm{Ca}^{2+}\right]_{\mathrm{i}}$ is modified in clinical and experimental hypertension. We found that basal $\left[\mathrm{Ca}^{2+}\right]_{\mathrm{i}}$ in $\mathrm{T}$ cells from SHR were lower than those from WKY rats, and feeding the Moringa oleifera diet, without affecting the basal $\left[\mathrm{Ca}^{2+}\right]_{\mathrm{i}}$ in lymphocytes from WKY rats, increased basal $\left[\mathrm{Ca}^{2+}\right]_{\mathrm{i}}$ in lymphocytes from SHR $(\mathrm{p}<0.05)$ (Fig. 8). Some studies have shown an increase in $\left[\mathrm{Ca}^{2+}\right]_{\mathrm{i}}$ in peripheral (Bruschi et al. 1985) and spleen T cells (Batlle et al. 1990), whereas others have not shown any significant differences of $\left[\mathrm{Ca}^{2+}\right]_{i}$ in lymphocytes from hypertensive subjects compared with normotensive individuals (Ricci et al. 1999). This discrepancy might be largely due to a heterogeneity of lymphocyte populations and differences in the protocols and techniques used to determine the increases of $\left[\mathrm{Ca}^{2+}\right]_{\mathrm{i}}$. We employed the double excitation technique, i.e. excitation at two wavelengths to determine $\left[\mathrm{Ca}^{2+}\right]_{\mathrm{i}}$ levels. This technique corrects the error that is usually caused by the shift in the spectrum from one wavelength to another during the increases in $\left[\mathrm{Ca}^{2+}\right]_{i}$ if the cells are excited at one wavelength.

We found that basal $\left[\mathrm{Ca}^{2+}\right]_{\mathrm{i}}$ in T cells from SHR were lower than those from WKY rats $(\mathrm{p}<0.05)$. The feeding of Moringa oleifera diet increased basal $\left[\mathrm{Ca}^{2+}\right]_{\mathrm{i}}$ in lymphocytes from SHR but not in those from WKY rats. These observations demonstrated that $\mathrm{T}$ cells from SHR have lower basal calcium concentrations compared with those from WKY rats, and the Moringa oleifera diet can correct this difference.

The density of calcium channels in $\mathrm{T}$ cells of SHR has not been examined. It is possible that plasma membrane properties may be altered in T cells from SHR as evidenced by the difference in fatty acid composition of phospholipids of $\mathrm{T}$ cells, particularly the contents of arachidonic acid, in SHR and WKY rats. It remains to determine how these modifications in plasma membrane phospholipids are involved in the modulation of calcium channels in T cells from SHR and WKY rats. However, a number of anomalies have been described in lymphocytes from hypertensive rats and humans including increased $\mathrm{Na}^{+}$influx and $\mathrm{K}^{+}$efflux, enhanced $\mathrm{Na}^{+}-\mathrm{H}^{+}$and $\mathrm{Na}^{+} / \mathrm{Ca}^{2+}$ exchanger activities (Bruschi et al. 1985). Hence, we hypothesize that the plasma membranes of $\mathrm{T}$ cells from SHR may have different composition than those of WKY rats. This is supported by the findings of Ebata et al. (1999) who reported an increased density of L-type calcium channels in heart and brain of SHR.

Cell activation is mediated via the TCR-CD3 complex. Stimulation of the TCR by antigen presented by the MHC rapidly leads to tyrosine phosphorylation and activation of adapter molecules and enzymes, including the linker for activation of $\mathrm{T}$ cells (LAT) and phospholipase $\mathrm{C} \gamma$ (PLC $\gamma$ ) (Kane et al. 2000). PLC $\gamma$ activity elicits a rise in cytoplasmic calcium concentration, a key event of $\mathrm{T}$ cell activation (Berridge et al. 2000). The activation of further signaling mediators is partially dependent on costimulatory signals that are triggered via costimulatory cell surface receptors such as CD28 or CD59 (Schwartz 1992, Deckert et al. 1992). In consequence to early protein phosphorylation steps and calcium response, mitogen-activated protein kinases (MAPKs) are activated by phosphorylation. The three major families of MAPKs, extracellular signal-regulated kinases (ERK), c-Jun NH2-terminal kinases (JNK), and p38 MAPK, are regulated by distinct but cross-talking signaling cascades (Garrington and Johnson 1999). Such signals culminate in the activation of transcription factors such as NF-AT, AP-1, and NF-kB (Masuda et al. 1998, Baeuerle and Henkel 1994). These transcription factors bind recognition sites within promoter sequences to induce transcription of cytokines, including IL-2, the major T lymphocyte proliferation factor (Cantrell 1996). Thus, T cell stimulation leads to IL-2 production and proliferation, thereby promoting the adaptive immune response.

PUFA treatment of human $T$ cells diminishes TCR/CD3-induced calcium response and proliferation (Stulnig et al. 1998, Rossetti et al. 1997). Furthermore, a decrease in IL-2 production in Jurkat T cells treated with PUFAs has recently been reported (Arrington et al. 
2001). However, the particular events of $T$ cell signal transduction downstream of the calcium response that are affected by PUFAs are still unresolved. Furthermore, the expression of IL-2, IL-2R-chain and IL-13 were significantly diminished in PUFA-treated peripheral blood T lymphocytes, while the expression of other cytokines and activation markers remained unaffected. By providing detailed insight into the influence of PUFAs on human $\mathrm{T}$ cell activation, these data considerably enhance our understanding of how these substances exert their immunomodulatory effects.

In conclusions, the Moringa oleifera extract is readily available and might be a novel drug candidate. More studies are needed, however, to examine therapeutic applications of the Moringa oleifera extract in the future, particularly on the use of known immunosuppressors during the progression of cardiovascular pathology in hypertensive subjects. Our study clearly demonstrated that Moringa oleifera diet exerts antihypertensive effects by inhibiting the secretion of IL-2 and modulating calcium homeostasis in T cells of these rats.

\section{Conflict of Interest}

There is no conflict of interest.

\section{Acknowledgements}

The authors thank the Ministry of Higher Education and Research of Benin. We also express our sincere gratitude to the French Ministry of Research which granted a contingent grant for Laboratoire de Physiopathologie Moléculaire et Toxicologie. We highly appreciate the contribution of Professor Naim Akhtar Khan who established the collaboration between Dijon (France) and Cotonou (Benin).

\section{References}

AIRES V, ADOTE S, HICHAMI A, MOUTAIROU K, BOUSTANI ES, KHAN NA: Modulation of intracellular calcium concentrations and T cell activation by prickly pear polyphenols. Mol Cell Biochem 260: 103-110, 2004.

AJA PM, NWACHUKWU N, IBIAM UA, IGWENYI IO, OFFOR CE, ORJI UO: Chemical constituents of Moringa oleifera leaves and seeds from Abakaliki, Nigeria. Am J Phytomed Clin Ther 3: 310-321, 2014.

ALFAIA CPM, ALVES SP, MARTINS SIV, COSTA ASH, FONTES CMGA, LEMOS JPC, BESSA RJB, PRATES JAM: Effect of the feeding system on intramuscular fatty acids and conjugated linoleic acid isomers of beef cattle, with emphasis on their nutritional value and discriminatory ability. Food Chem 114: 939-946, 2009.

ANWAR F, LATIF S, ASHRAF M, GILANI AH: Moringa oleifera: A food plant with multiple medicinal uses. Phytother Res 21: 17-25, 2007.

ARRINGTON JL, MCMURRAY DN, SWITZER KC, FAN YY, CHAPKIN RS: Docosahexaenoic acid suppresses function of the CD28 costimulatory membrane receptor in primary murine and Jurkat T cells. $J$ Nutr 131: 1147-1153, 2001.

BAEUERLE PA, HENKEL T: Function and activation of NF- $\kappa \mathrm{B}$ in the immune system. Annu Rev Immunol 12: 141-179, 1994.

BATLlE DC, JANSS G, LAPOINTE M, LLIBRE J, SALEH A: Cytosolic calcium in T lymphocytes from the spontaneously hypertensive rat. Am J Hypertens 3: 343-348, 1990.

BAYTOP T: Therapy with Medicinal Plants in Turkey (Past and Present). Nobel Press, Istanbul, 1984.

BERRIDGE MJ, LIPP P, BOOTMAN MD: The versatility and universality of calcium signalling. Nat Rev Mol Cell Biol 1: 11-21, 2000.

BLIGH EG, DYER WJ: A rapid method of total lipid extraction and purification. Can J Biochem Physiol 37: 911-917, 1959.

BONAA KH, BJERVE KS, STRAUME B, GRAM IT, THELLE D: Effect of eicosapentaenoic and docosahexaenoic acids on blood pressure in hypertension - A population-based intervention trial from the Tromso study. $N$ Engl J Med 322: 795-801, 1990.

BRICKMAN AS, NYBY MD, VON HUNGEN K, EGGENA P, TUCK ML: Calciotropic hormones, platelet calcium, and blood pressure in essential hypertension. Hypertension 16: 515-522, 1990. 
CÁCERES A, SARAVIA A, RIZZO S, ZABALA L, De LEON E, NAVE F: Pharmacologic properties of Moringa oleifera. 2: Screening for antispasmodic, antiinflammatory and diuretic activity. $J$ Ethnopharmacol 36: 233-237, 1992.

CALDER PC: Dietary fatty acids and immune system. Lipids 34 (Suppl): S137-S140, 1999.

CALDER PC, KRAUSS-ETSCHMANN S, DE JONG EC, DUPONT C, FRICK JS, FROKIAER H, HEINRICH J, GARN H, KOLETZKO S, LACK G, ET AL.: Early nutrition and immunity - progress and perspectives. Br J Nutr 96: 774-790, 2006.

CANTRELL D: T cell antigen receptor signal transduction pathways. Annu Rev Immunol 14: 259-274, 1996.

CHAN M: Address at the WHO Congress on Traditional Medicine. WHO 2008. http://www.who.int/dg/speeches/2008/20081107/en/.

DECKERT M, KUBAR J, BERNARD A: CD58 and CD59 molecules exhibit potentializing effects in T-cell adhesion and activation. J Immunol 148: 672-677, 1992.

EBATA H, NATSUME T, MITSUHASHI T: Reduced calcium sensitivity and density of dihydropyridine binding to calcium channels in spontaneously hypertensive rats. Hypertension 17: 2234-2241, 1999.

ENDRES S, MEYDANI SN, GHORBANI R, SCHINDLER R, DINARELLO CA: Dietary supplementation with n-3 fatty acids suppresses interleukin-2 production and mononuclear cell proliferation. J Leukoc Biol 54: 599-603, 1993.

FAHEY JW: Moringa oleifera: A review of medical evidence for its nutritional, therapeutic and prophylactic properties. Tree Life J 1: 5, 2005.

FRENOUX JM, PROST ED, BELLEVILLE JL, PROST JL: A polyunsaturated fatty acid diet lowers blood pressure and improves antioxidant status in spontaneously hypertensive rats. $J$ Nutr 131: 39-45, 2001.

FU ML: Abnormal immune system and hypertension: where are we? Ann Med 27: 671-674, 1995.

GARRINGTON TP, JOHNSON GL: Organization and regulation of mitogen-activated protein kinase signaling pathways. Curr Opin Cell Biol 11: 211-218, 1999.

GIVEN MB, LOWE RF, WILLIAMS DL, SANDER GE, GILES TD: Failure of interleukin-2 to alter systolic blood pressure in Dahl salt-sensitive rats. Am J Hypertens 5: 203-204, 1992.

GRIFFIN BA: How relevant is the ratio of dietary $n-6$ to $n-3$ polyunsaturated fatty acids to cardiovascular disease risk? Evidence from the OPTILIP study. Curr Opin Lipidol 19: 57-62, 2008.

GRYNKIEWICZ G, POENIE M, TSIEN RY: A new generation of $\mathrm{Ca}^{2+}$ indicators with greatly improved fluorescence properties. J Biol Chem 260: 3440-3450, 1985.

GUDBRANDSSON T, HERLITZ H, LINDHOLM L, NILSSON LA, HANSSON L: Immunological changes in patients with previous malignant essential hypertension. Lancet 1: 406-408, 1981.

GULATI K, RAY A, DEBNATH PK, BHATTACHARYA SK: Immunomodulatory Indian medicinal plants. $J$ Nat Remedies 2: 121-131, 2002.

HICHAMI A, DATICHE F, ULLAH S, LIÉNARD F, CHARDIGNY JM, CATTARELLI M, KHAN NA: Olfactory discrimination ability and brain expression of c-fos, Gir and Glut1 mRNA are altered in n-3 fatty acid-depleted rats. Behav Brain Res 184: 1-10, 2007.

HILME E, HANSSON L, SANDBERG L, SODERSTRO MT, HERLITZ H: Abnormal immune function in malignant hypertension. J Hypertens 11: 989-994, 1993.

HOFFMAN LC, WIKLUND E: Game and vension-meat for the modern consumers. Meat Sci 74: 197-208, 2006.

HUNG P, KAKU S, YUNOKI S, OHKURA K, GU JY, IKEDA I, SUGANO M, YAZAWA K, YAMADA K: Dietary effects of eicosapentaenoic and docosahexaenoic acid esters on lipid metabolism and immune parameters in Sprague-Dawley rats. Biosci Biotechnol Biochem 63: 135-140, 1999.

JOLLY CA, JIANG YH, CHAPKIN RS, MCMURRAY DN: Dietary (n-3) polyunsaturated fatty acids suppress murine lymphoproliferation, interleukin-2 secretion, and the formation of diacylglycerol and ceramide. $J$ Nutr 127: 37-43, 1997.

KAGAWA H, NOMURA S, OZAKI Y, NAGAHAMA M, FUKUHARA S: Effects of nilvadipine on cytokine-levels and soluble factors in collagen disease complicated with hypertension. Clin Exp Hypertens 21: 1177-1188, 1999.

KANE LP, LIN J, WEISS A: Signal transduction by the TCR for antigen. Curr Opin Immunol 12: 242-249, 2000. 
KASOLO JN, BIMENYA GS, OJOK L, OCHIENG J, OGWAL-OKENG JW: Phytochemicals and uses of Moringa oleifera leaves in Ugandan rural communities. J Med Plant Res 4: 753-757, 2010.

KHOTIMCHENKO SV: Lipids from the marine alga Gracilaria verrucosa. Chem Nat Compd 41: 285-288, 2005.

KING GL: The role of inflammatory cytokines in diabetes and its complications. J Periodontol 79: 1527-1534, 2008.

KRISTENSEN BO: Increased serum levels of immunoglobulins in untreated and treated essential hypertension. Acta Med Scand 203: 49-54, 1978.

KRUIT WH, SCHMITZ PI, STOTER G: The role of risk factors for acute and late renal dysfunction after interleukin-2, interferon alpha and lymphokines-activated killer cells. Cancer Immunol Immunother 48: 331-335, 1999.

LE QUAN SANG KH, DEVYNCK MA: Increased platelet cytosolic free Ca concentration in essential hypertension. J Hypertens 4: 567-574, 1986.

MANHART N, VIERLINGER K, AKOMEAH R, BERGMEISTER H, SPITTLER A, ROTH E: Influence of enteral diets supplemented with key nutrients on lymphocyte subpopulations in Peyer's patches of endotoxinboostered mice. Clin Nutr 19: 265-269, 2000.

MASUDA ES, IMAMURA R, AMASAKI K, ARAI K, ARAI N: Signalling into the T-cell nucleus: NFAT regulation. Cell Signal 10: 599-611, 1998.

MATSUMORI A, YAMADA T, SUZUKI H, MATOBA Y, SASAYAMA S: Increased circulating cytokines in patients with myocarditis and cardiomyopathy. Br Heart J 72: 561-566, 1994.

MBIKAY M: Therapeutic potential of Moringa oleifera leaves in chronic hyperglycemia and dyslipidemia: A review. Front Pharmacol 3: 24, 2012.

MCMURRAY DN, JOLLY CA, CHAPKIN RS: Effects of dietary n-3 fatty acids on T cell activation and T cell receptor-mediated signaling in a murine model. J Infect Dis 182 (Suppl 1): S103-S107, 2000.

MISHRA G, SINGH P, VERMA R, KUMAR S, SRIVASTAV S, JHA KK: Traditional uses, phytochemistry and pharmacological properties of Moringa oleifera plant: An overview. Der Pharmacia Lettre 3: 141-164, 2011.

OFOSU-APPIAH W, RUGGIERO C: Abnormal activation and loss of suppressor $\mathrm{T}$ cells in the spontaneous hypertensive rat. Cell Immunol 145: 130-145, 1992.

OSHIMA T, YOUNG EW, MCCARRON DA: Abnormal platelet and lymphocyte $\mathrm{Ca}^{2+}$ handling in prehypertensive rats. Hypertension 18: 111-115, 1991.

PEETERS AC, NETEA MG, JANSSEN MC, KULLBERG BJ, VAN DER MEER JW, THIEN T: Pro-inflammatory cytokines in patients with essential hypertension. Eur J Clin Invest 31: 31-36, 2001.

POCKAJ BA, ROSENBERG SA: Lack of antihypertensive effect of interleukin-2 administration in humans. $J$ Immunother 10: 456-459, 1991.

PRITCHARD K, RAINE AE, ASHLEY CC, CASTELL LM, SOMERS V, OSBORN O, LEDINGHAM JG, CONWAY J: Correlation of blood pressure in normotensive and hypertensive individuals with platelet but not lymphocyte intracellular free Ca concentrations. Clin Sci 76: 631-635, 1989.

RICCI A, BRONZETTI E, FERRANTE F, MIGNINI F, MULATERO P, SCHENA M, VEGLIO F, AMENTA F: Ca ${ }^{2+}$ channels of the L-type in peripheral blood lymphocytes of essential hypertensives. Am J Hypertens 12: 40-46, 1999.

ROSSETTI RG, SEILER CM, DELUCA P, LAPOSATA M, ZURIER RB: Oral administration of unsaturated fatty acids: effects on human peripheral blood T lymphocyte proliferation. J Leukocyte Biol 62: 438-443, 1997.

SASAKI T, KANKE Y, KUDOH K, MISAWA Y, SHIMIZU J, TAKITA T: Effects of dietary docosahexaenoic acid on surface molecules involved cell proliferation. Biochim Biophys Acta 1436: 519-530, 1999.

SASAKI T, KANKE Y, KUDOH K, NAGAHASHI M, TOYOKAWA M, MATSUDA M, SHIMIZU J, TAKITA T: Dietary n-3 polyunsaturated fatty acid and status of immunocompetent cells involved in innate immunity in female rats. Ann Nutr Metab 44: 38-42, 2000a.

SASAKI T, KANKE Y, NAGAHASHI M, TOYOKAWA M, MATSUDA M, SHIMIZU J, MISAWA Y, TAKITA T: Dietary docosahexaenoic acid can alter the surface expression of CD4 and CD8 on T cells in peripheral blood. J Agric Food Chem 48: 1047-1049, 2000b.

SCHWARTZ RH: Costimulation of T lymphocytes: the role of CD28, CTLA-4, and B7/BB1 in interleukin-2 production and immunotherapy. Cell 71: 1065-1068, 1992. 
SIMOPOULOS AP: Omega-3 fatty acids in health and disease and in growth and development. Am J Clin Nutr 54: 438-463, 1991.

SINGER P, BERGER I, MORITZ V, FORSTER D, TAUBE C: n-6 and n-3 PUFA in liver lipids, thromboxane formation and blood pressure from SHR during diets supplemented with evening primrose, sunflowerseed or fish oil. Prostaglandins Leukot Essent Fatty Acids 39: 207-211, 1990.

STAMPFER MJ, HU FB, MANSON JE, RIMM EB, WILLET WC: Primary prevention of coronary heart disease in women through diet and life style. $N$ Engl J Med 343: 16-22, 2000.

STULNIG TM, BERGER M, SIGMUND T, RAEDERSTORFF D, STOCKINGER H, WALDHÄUSL W: Polyunsaturated fatty acids inhibit $\mathrm{T}$ cell signal transduction by modification of detergent-insoluble membrane domains. J Cell Biol 143: 637-648, 1998.

TOMOBE YI, MORIZAWA K, TSUCHIDA M, HIBINO H, NAKANO Y, TANAKA Y: Dietary docosahexaenoic acid suppresses inflammation and immunoresponses in contact hypersensitivity reaction in mice. Lipids $\mathbf{3 5}$ : 61-69, 2000.

TUTTLE RS, BOPPANA DP: Antihypertensive effect of interleukin-2. Hypertension 15: 89-94, 1990.

WICK G: Atherosclerosis - an autoimmune disease due to an immune reaction a heat-shock protein 60. Herz 25: 87-90, 2000.

WOOD JD, RICHARDSON RI, NUTE GR, FISHER AV, CAMPO MM, KASAPIDOU E, SHEARD PR, ENSER M: Effect of acids on meat quality: a review. Meat Sci 66: 21-32, 2004.

YOSEFY C, VISKOPER JR, VARON D, ILAN Z, PILPEL D, LUGASSY G, SCHNEIDER R, SAVYON N, ADAN Y, RAZ A: Repeated fasting and refeeding with 20:5, n-3 eicosapentaenoic acid (EPA): a novel approach for rapid fatty acid exchange and its effect on blood pressure, plasma lipids and homeostasis. J Hum Hypertens 10 (Suppl 3): S135-S139, 1996. 